\title{
PEMBERDAYAAN SOCIAL SUPPORT GROUP DALAM ADAPTASI NORMALISASI PADA ORANGTUA DENGAN ANAK KANKER DI KOTA BANDUNG BANDUNG
}

\author{
Ikeu Nurhidayah ${ }^{1}$, Sri Hendrawati ${ }^{2}$, dan Titin Sutini ${ }^{3}$ \\ ${ }^{1,2}$ Departemen Keperawatan Anak, Fakultas Keperawatan, Universitas Padjadjaran \\ ${ }^{3}$ Departemen Keperawatan Jiwa, Fakultas Keperawatan, Universitas Padjadjaran \\ E-mail: ikeu.nurhidayah@unpad.ac.id
}

\begin{abstract}
ABSTRAK. Kanker merupakan salah satu masalah kesehatan kronis pada anak yang semakin meningkat, Kanker anak memerlukan proses pengobatan yang panjang, yang akan berdampak bukan hanya pada anak, namun juga pada orangtua dan keluarga. Keluarga dengan anggota keluarga akan mengalami berbagai perubahan yang mengganggu kehidupan keluarga. Fokus grup diskusi dengan orangtua menunjukkan orangtua merasakan stres yang sangat luar biasa. Orangtua harus dapat melakukan berbagai penyesuaian serta membantu anak untuk beradaptasi dengan penyakitnya melalui proses normalisasi. Normalisasi keluarga dipengaruhi oleh berbagai faktor, salah satunya adalah dukungan melalui social support group dari keluarga, peer group, tenaga profesional dan kader kesehatan. Kegiatan ini berupa pemberdayaan social support group di rumah singgah Yayasan Kasih Anak Kanker Indonesia Bandung. Khalayak sasaran pada kegiatan ini adalah peer group (sesama orang tua dengan anak penyandang kanker), volunteer dan kader kesehatan sejumlah 38 orang. Luaran kegiatan ini adalah peningkatan kemampuan kognitif dan psikomotor orang tua, kader kesehatan dan volunteer dalam memberikan dukungan keluarga dengan kanker untuk melakukan adaptasi dan proses normalisasi. Metode kegiatan ini dilakukan dengan ceramah, simulasi, small group discussion dan praktikum. Hasil kegiatan menunjukkan bahwa rata-rata skor pengetahuan partisipan sebelum dilakukan kegiatan pemberdayaan adalah 65,20 (SD: 0,2), dan rata-rata skor pengetahuan setelah dilakukan kegiatan adalah 87,4 (SD: 0,2), dengan rata-rata peningkatan skor 22,2 (SD: 0,12), dan kemampuan psikomotor peserta 100\% dalam kategori baik. Hasil kegiatan ini merekomendasikan yayasan YKAKI untuk membentuk social support group untuk mendukung orantua dan keluarga dengan anak kanker.
\end{abstract}

Kata Kunci: Kanker anak, keluarga, pemberdayaan, social support group.

ABSTRACT. Cancer is one of the increasingly chronic health problems in children. Cancer treatment requires a very long time for caring, which will impact not only on the child, but also on parents and family. Families will experience a variety of changes that is a crisis situation that can disrupt the balance of life. The focus group conducted with Indonesian Childhood Cancer Foundation Bandung, showed that parents experience the extraordinary stress and family disruption. Parents should be able to make various adjustments and help children to adapt to the illness through normalization process. The process of family normalization is influenced by various factors, one of which is support through social support group from families, professionals and community volunteer. Target audience in this social service were volunteer, health cadres, and parents of childhood cancer Bandung totaling 38 people. The outcomes of this activity were the improvement of cognitive and psychomotor participant's capabilities in providing family support. Delivery method in this social services were lecture, simulation, small group discussion. The results showed that the mean score of participans knowledge before empowerment activity was 65,20 (SD: 0.2), and 87,40 (SD: 0.31 ) after, with increases mean score is 22,2 (SD: 0.12), and psychomotor ability of $100 \%$ participants in excellent category. The results of this activity recommends to continue the empowerment of family to improve the quality of life in children with cancer and their families. These activities will be services as parent-family social support group among childhoods cancer's parents in Bandung.

Key words: Childhood-cancer, family-empowerment, social support group.

\section{PENDAHULUAN}

Penyakit kronis pada anak merupakan kondisi yang memengaruhi fungsi sehari-hari selama lebih dari 3 bulan dalam setahun, sehingga menyebabkan anak menjalani proses hospitalisasi lebih dari 1 bulan dalam 1 tahun. Penyakit kronis yang sering terjadi pada anak, diantaranya penyakit kardiovaskuler, penyakit kanker dan hematologi, penyakit kronis pernafasan, gangguan endokrin, gangguan imunologi, penyakit gagal ginjal, penyakit kulit, dan anak berkebutuhan khusus. Data statistik menunjukkan bahwa setidaknya terdapat satu dari sepuluh $(1: 10)$ anak usia dibawah 15 tahun mengalami sakit kronis (Theofanidis, 2006). Studi epidemiologis lainnya memperkirakan bahwa satu pertiga (1/3) anak dibawah usia 18 tahun mengalami satu atau lebih kondisi atau penyakit kronis (Shah,
Harrington, Huber, Wellnich, Fridrichy, \& Laser, 2003; Costello, Folley, \& Angold, 2006). Sakit kronis dapat memengaruhi kondisi anak dan keluarga. Anak dan keluarga dapat mengalami mental shock, sentiments of anger, berduka, dan distres berkepanjangan (McClellan $\&$ Cohen, 2007). Kanker merupakan salah satu penyakit kronis yang paling seringkali diderita oleh anak.

Permasalahan kanker anak di Indonesia saat ini menjadi persoalan yang cukup besar (Kementerian Kesehatan RI, 2013). Menurut Gatot (2008), prevalensi kanker anak di Indonesia mencapai empat (4)\%, artinya dari seluruh angka kelahiran hidup anak Indonesia, empat (4)\% diantaranya akan mengalami kanker. Saat ini kanker menjadi sepuluh besar penyakit utama yang menyebabkan kematian anak di Indonesia (Depkes RI, 2011). Fakta mengenai hal tersebut didukung oleh data dari beberapa 
rumah sakit rujukan seperti di Rumah Sakit Umum Pendidikan Nasional (RSUPN) Dr. Cipto Mangunkusumo Jakarta dan RSUP Dr. Hasan Sadikin Bandung pada tahun 2013 yang menunjukkan kanker menjadi lima besar penyakit pada anak yang dirawat.

Kondisi sakit kronis, seperti kanker yang dialami anak merupakan tantangan yang sulit bagi anak, yang mungkin merasa takut terhadap kondisi sakitnya, prosedur laboratorium dan diagnosis, serta proses pengobatan yang harus dijalaninya (Hockenberry \& Wilson, 2012). Apalagi kanker pada anak merupakan salah satu penyakit kronis dengan proses pengobatan yang panjang, menyakitkan dan menimbulkan berbagai efek samping (Wenar \& Kerig, 2005). Anak dengan sakit kronis, tidak begitu saja mengikuti intervensi pengobatan dengan mudah, sehingga kebutuhan akan dukungan dari keluarga dan tenaga kesehatan sangat diperlukan. Kondisi akan lebih buruk jika anak merasa bersalah karena keyakinannya bahwa penderitaan yang dialami dikarenakan hukuman atau dosa anak sebelumnya (Wong, 2013; Peck \& Lillibridge, 2005). Pada beberapa keadaan, anak mungkin melihat bahwa situasi kronis ini akan berlangsung permanen dan menyebabkan ketakutan yang berlangsung progresif sehingga menjadi lebih buruk. Pada beberapa keadaan, anak mengalami panik dan selanjutnya kondisi ini akan memengaruhi gejala dan kemampuan koping anak (Hockenberry \& Wilson, 2012).

Anak yang mengalami stres (insecure child) dapat meningkatkan stres orangtua. Lebih jauh, hal ini dapat meningkatkan stres pada anak dan mungkin mengganggu keseimbangan proses keluarga (Peck \& Lillibridge, 2005). Beberapa reaksi psikososial anak terhadap kondisi sakit kronis, diantaranya ketakutan akan penolakan (fear of rejection), harga diri rendah, merasa tidak aman, keterbatasan dalam pendidikan, ketakukan akan keterbatasan lainnya, dan kecemasan akan reaksi orang lain (Herminia \& Joao, 2006). Respon anak terhadap kondisi sakit kronis sangat dipengaruhi oleh kepribadian, usia, perilaku sosial, dan hubungan anak dengan orangtua. Namun demikian, mayoritas anak memiliki keinginan yang kuat untuk pemulihan yang tepat dengan mempelajari teknik-teknik yang dapat meringankan kondisi mereka. Hal ini dapat terjadi dengan dukungan orangtua dan profesional kesehatan yang sangat penting, sehingga anak memahami kondisi hospitalisasi. Hal ini selanjutnya akan meningkatkan kepercayaan diri anak untuk menghadapi situasi sulit di masa yang akan datang (Sarafino, 2018).

Walaupun beberapa gejala sangat bervariasi pada setiap anak dengan kondisi kronis, namun perasaan nyeri dan putus asa merupakan hal yang sangat sering terjadi (Hockenberry \& Wilson, 2009; Wong, 2009). Traumatik pada anak dapat terjadi akibat hospitalisasi dan prosedur invasif yang sering dijalani. Penolakan sosial dari teman sebaya juga dapat meningkat dan dapat menurunkan keinginan anak untuk berprestasi. Pembatasan yang diterima anak sehubungan dengan kondisi sakitnya dapat berakibat pada perasaan tidak percaya diri dan merasa berbeda dari anak lain. Hal ini memerlukan intervensi dari orangtua dan tenaga kesehatan terutama perawat. Tanpa dukungan keduanya, kondisi ini akan meningkatkan ketergantungan anak terhadap orangtua atau caregiver, menurunkan inisiatif (lack of initiatives), dan selanjutnya akan menyebabkan anak tereksklusi dari aktivitas sosial, meningkatkan distres, dan overprotection dari orangtua (Coffey, 2006; Theofanidis, 2006).

Selain memengaruhi anak, sakit kronis juga memengaruhi orangtua (Theofanidis, 2006). Kondisi yang sangat natural bagi orangtua untuk mengalami putus asa dan distres ketika mendapati anaknya memiliki sakit serius dan kronis yang mungkin akan berlangsung lama. Identitas orangtua dapat terancam apabila mereka merasa bertanggung jawab terhadap lahirnya anak yang tidak sehat, merasa tidak dapat melindungi anak dari penyakit kronis atau kelemahan, bahkan dapat mengalami kesedihan saat menerima kenyataan bahwa anaknya tidak akan berkembang seperti anak-anak lain seusianya. Hal ini dapat merusak filosofi, nilai-nilai, impian, dan harapan keluarga. Beberapa orangtua dapat merasa putus asa untuk mengelola situasi ini dan hanya berfokus pada jangka pendek untuk mengatasi masalah kesehatan anak dari hari ke hari tanpa tujuan jangka panjang. Orangtua berjuang untuk bertahan hidup dalam menghadapi situasi yang sulit ini (Hockenberry \& Wilson, 2012; McMullen et al., 2007; McQuaid et al., 2005). Setiap keluarga memiliki pengalaman psikologis yang berbeda dalam menjalani kehidupan dengan anak sakit kronis ini, sehingga kebutuhan terhadap dukungan dari luar juga bervariasi. Setidaknya harus terdapat tiga sumber dukungan, diantaranya dukungan profesional dari petugas kesehatan, dukungan keluarga atau kerabat/tetangga dekat atau orang yang dihormati (kader kesehatan), dan dukungan sesama orangtua dengan anak sakit kronis (Hockenberry \& Wilson, 2012; Wong, 2013).

Komunikasi terbuka dan sharing merupakan hal yang konstruktif dalam beradaptasi terhadap penyakit kronis yang dialami anak. Komunikasi dan sharing tidak terbatas pada penyakit dan cara pengobatannya, tetapi juga mengenai ekspresi dan persepsi terhadap penyakit kronis yang dialami anak. Apabila sistem dukungan berfungsi konstruktif, maka hal ini akan meningkatkan keeratan keluarga dengan pembagian tugas yang konstruktif tanpa hanya memberatkan kondisi orangtua saja (Knafl et al., 2013). Keluarga dan dukungan sosial lainnya yang saling bekerjasama dan berkolaborasi dapat memberikan rasa aman dan kasih sayang terhadap orangtua dan anak sakit kronis untuk menghadapi penyakitnya. Dalam lingkungan yang kondusif ini, semua caregiver akan menyesuaikan diri dan berkomunikasi dengan lebih efektif mengenai semua aspek kondisi anak sakit kronis, termasuk kemungkinan dalam menghadapi kematian (Matson, 2009).

Masalah yang sering dihadapi saat ini yaitu beberapa orangtua masih memiliki sikap tertutup dan 
menyembunyikan penyakit anaknya, pengobatan, dan prognosisnya. Selain itu, beberapa petugas kesehatan juga sering bersikap over-protective sehingga gagal untuk menginformasikan kepada orangtua dan anak mengenai penyakit, pengobatan, dan prognosisnya. Hal ini terutama mungkin terjadi apabila anak menderita penyakit yang mengancam jiwa. Terkadang petugas kesehatan mengabaikan salah satu kebutuhan yang paling dasar, yaitu keingintahuan orangtua dan anak terhadap penyakit dan prognosis kedepannya (Wirlach and Bartosik, Schubert, Freilinger, \& Schober, 2005). Orangtua dengan anak sakit kronis memiliki tugas untuk mendukung dan mendampingi tumbuh kembang anak agar menjadi anak yang tidak hanya lebih sehat secara fisik namun juga memiliki keunggulan karakter dan tentunya hal ini menjadi tantangan yang besar. Orangtua dengan anak sakit kronis selain menjalankan peran umum sebagai orangtua, juga memiliki tanggungjawab lain terkait manajemen gejala, perawatan dan pengobatan anaknya, serta memiliki tugas untuk mencari pelayanan kesehatan yang tepat untuk anaknya (Hockenberry \& Wilson, 2012; Coffey, 2006).

Orangtua seringkali kurang siap dalam menghadapi berbagai masalah yang muncul baik saat anak didiagnosis, mengalami transisi perkembangan, perawatan yang harus dilakukan secara terus menerus, maupun dalam menghadapi kekambuhan (Hockenberry \& Wilson, 2012). Stresor ini memunculkan dampak psikologis, sosial dan ekonomi. Berdasarkan hasil penelitian yang dilakukan oleh Coffey (2006), menunjukkan bahwa orangtua dengan anak sakit kronis dapat mengalami perasaan khawatir, putus asa, exhaustion, hopelessness, overwhelmed, dan merasa diri tidak berdaya dalam menghadapi penyakit anaknya. Orangtua berperan menjadi caregiver utama, bahkan hal ini dapat mengganggu pekerjaan orangtua karena sebagian besar waktu terfokus pada anak yang sedang sakit. Sehingga orangtua harus mampu membagi tugas dalam keluarga, meminimalkan reaksi sibling, dan berusaha mencari pelayanan kesehatan terbaik untuk anaknya. Mengatasi permasalahan yang muncul pada diri sendiri merupakan batu pijakan pertama bagi orangtua sebelum membantu mengatasi masalah pada anak dan mampu membentuk karakter unggul pada anak. Selain itu, mencari dukungan sosial dari para profesional kesehatan interdisipliner dalam menghadapi setiap tahapan stresor juga penting.

Dalam menghadapi penyakit kronis pada anak yang tekanannya lebih pada perawatan, orangtua seringkali merasa sendirian dalam berjuang menghadapi stresor yang terus berlangsung dan beragam. Meskipun stresor ini bervariasi sepanjang waktu, namun dapat dikategorikan dalam empat macam situasi yang menyebabkan orangtua mengalami stres, yaitu pada saat diagnosis, selama waktu transisi perkembangan penyakit, hal-hal yang berkaitan dengan kebutuhan perawatan kesehatan anak, dan ketika anak mengalami kekambuhan penyakit dan harus menjalankan hospitalisasi (Hockenberry \& Wilson, 2009).
Tidak semua keluarga dapat menerima dan menyesuaikan diri dengan cepat ketika menghadapi stresor tersebut. Dampak yang dirasakan sangat beragam, baik secara sosial, ekonomi, maupun psikologis (Wong, 2009; Coffey, 2006; McQuaid et al., 2005; Mc. Mullen et al., 2007; Brazil \& Kruger, 2002).

Keluarga memiliki peran yang sangat penting dalam mendampingi anak dengan sakit kronis untuk dapat beradaptasi terhadap penyakit yang dialaminya. Normalisasi merupakan suatu proses dimana keluarga mencoba untuk menormalkan kehidupan sehari-hari mereka sementara memiliki anak dengan penyakit kronis (Huang, 2003). Keluarga harus mampu beradaptasi dalam menjalani kehidupan sehari-hari, termasuk dalam mengakomodasi kebutuhan anak, baik secara fisik maupun psikologis (Hockenberry \& Wilson, 2012; O’Neal, 2007). Orangtua melakukan berbagai strategi koping untuk mencapai keseimbangan dalam kehidupannya tersebut (Knafl, Darney, Gallo, \& Angst, 2010; Peck \& Lillibridge, 2005).

Konsep normalisasi menurut Knafl dan Deatrick (2002) terdiri dari beberapa elemen diantaranya mengakui bahwa terdapat gangguan atau keterbatasan akibat penyakit, mendefinisikan kehidupan pada dasarnya normal, meminimalkan dampak sosial dari penyakit, menunjukkan perilaku yang normal kepada orang lain, dan menjalani perawatan serta pengobatan terhadap penyakit anaknya. Dalam normalisasi ini, orangtua berusaha untuk menormalkan atau menerima bahwa terdapat penyimpangan dari kesehatan akibat penyakit kronis yang dialami anaknya, tetapi orangtua berusaha untuk hidup seperti biasanya dengan mengatasi keterbatasan yang dialami anaknya. Orang tua mungkin memanipulasi lingkungan dan menempatkan anak-anak mereka dalam situasi yang normal.

O'Niel (2007) menyatakan bahwa normalisasi merupakan suatu proses yang dinamis dan terjadi dari waktu ke waktu dimana terdapat interaksi terus-menerus antara apa yang dianggap normal yang diidentifikasi oleh individu dan apa karakteristik yang normal yang dapat dicapai atau dipertahankan, sehingga membentuk persepsi orang lain. Orangtua secara konsisten mengidentifikasi normalisasi sebagai tujuan yang dikembangkan untuk menciptakan dan mempertahankan kehidupan keluarga mereka seperti biasanya dan mencapai kepuasan. Normalisasi memerlukan upaya orangtua dan anggota keluarga lainnya untuk menciptakan kehidupan normal dalam keluarga (O'Niel, 2007).

Bagi orangtua, normalisasi merupakan kemampuan untuk menyeimbangkan manajemen gejala penyakit kronis pada anak dan aspek-aspek lain dari kehidupan keluarga yang dipandang sebagai bukti keberhasilan mereka sebagai orangtua dalam beradaptasi terhadap penyakit kronis yang dialami anaknya. Orangtua memiliki kemampuan untuk melaksanakan rejimen pengobatan dan bertindak sebagai advokat untuk anak-anak mereka dalam 
perawatan kesehatan baik di rumah maupun di sekolah. Selain mengelola rejimen pengobatan, orangtua juga harus membagi waktu untuk pekerjaannya dan anggota keluarga lainnya (Knafl, Darney, Gallo, \& Angst, 2010).

Ketika orangtua sudah bisa menyelesaikan masalahnya dengan baik, orangtua memiliki kesempatan untuk bisa membantu anak mengatasi permasalahan yang dihadapi anak berkaitan dengan sakit dan dampaknya. Orangtua menjadi model pengelolaan emosi bagi anak sehingga anak mampu mengontrol emosi yang dialami dan menjadi pribadi yang tangguh secara emosi. Pelibatan dalam perawatan dan kehidupan sehari-hari dapat membawa kemandirian pada anak, harga diri meningkat, mengurangi rasa bersalah dan tidak berdaya, serta kecemasan terhadap reaksi atau penolakan orang lain (Hockenberry \& Wilson, 2012).

Perawat memiliki peran yang unik dalam memfasilitasi transisi terkait dengan penyakit kronis (O’Niel, 2007). Dalam banyak hal, perawat memiliki kontak langsung dengan individu dan keluarga yang mengalami penyakit kronis. Hal ini memberikan perawat kesempatan untuk menilai strategi koping yang digunakan individu dan keluarganya (O’Neal, 2007). Normalisasi telah digunakan sebagai cara bagi perawat untuk mengevaluasi individu atau efektivitas keluarga dalam mengelola penyakit kronis. Sistem Klasifikasi Intervensi Keperawatan (NIC) mengidentifikasi bahwa normalisasi sebagai intervensi keperawatan, yang mendukung gagasan bahwa normalisasi adalah hal yang baik dan positif serta signifikan untuk keperawatan (McCloskey \& Bulchek, 2000). Anak dengan sakit kronis memiliki kebutuhan normal dan mencari gaya hidup yang dapat meningkatkan kesehatannya.

Orangtua yang memiliki anak dengan penyakit kanker menghadapi berbagai kesulitan biopsikososial sejalan dengan fase pengobatan yang dilalui anak mereka. Hal tersebut dapat diidentifikasi sebagai kondisi yang dapat mempengaruhi fungsi sosial orangtua (Puspita \& Ludiro, 2013). Social support group merupakan sumber yang unik dalam memberikan seperangkat manfaat bagi orang tua dengan anak yang berpenyakit kanker dalam hal adaptasi dan perkembangan psikososial. Social Support Group merupakan kelompok yang memberikan manfaat berupa informasi petugas kesehatan, kader kesehatan sebagai relawan (community volunteer) dan sesama orangtua yang memiliki anak dengan kanker (peer support). Social support group ini menawarkan saling bertukar pengalaman satu sama lain, anggota kelompok memaparkan dukungan dari relawan dan sesama orang tua pasien. Hal ini akan memberikan motivasi pada orangtua dalam mendampingi anaknya menjalani proses pengobatan.

Pengabdian Kepada Masyarakat (PPM) memiliki misi untuk ikut serta dalam memecahkan permasalahan yang ada di masyarakat. Sehingga kegiatan PPM ini merupakan media yang sangat tepat untuk memfasilitasi masyarakat, dalam hal ini orangtua anak dengan kanker untuk mendapatkan social support dari petugas kesehatan, kader kesehatan dan sesama orangtua anak dengan kanker (peer support) dalam adaptasi dan normalisasi pada kehidupan sehari-hari. PPM ini akan dilaksanakan di Kota Bandung, dengan sasaran kader kesehatan/ relawan (community volunteer) dan sesama orangtua yang memiliki anak dengan kanker (peer support).

Pengabdian Kepada Masyarakat (PPM) ini dilaksanakan melalui peningkatan peran serta kader kesehatan/relawan (community volunteer) dan orangtua anak dengan kanker (peer) melalui social support group di Wilayah Kota Bandung Bandung dalam adaptasi dan normalisasi yang harus orangtua lakukan terkait kondisi sakit anaknya. Melalui social support group ini orangtua dapat berbagi pengalaman dalam hal merawat anaknya dan dalam hal saling memberikan dukungan, melalui dukungan emosional, dukungan penghargaan, dukungan instrumental, dan dukungan informatif yang diberikan oleh social support group. Orangtua juga dapat mengoptimalkan adanya peer education dan mentoring, peer advisor dan listening, peer mediation, dan self help group pada social support group terkait perawatan dan pengobatan pada anak. PPM ini dilaksanakan bekerjasama dengan pengelola di Yayasan Kasih Kanker Anak Indonesia Cabang Bandung.

Yayasan Kanker Indonesia (YKAKI) Cabang Bandung merupakan yayasan non profit yang bergerak di bidang kemanusiaan dengan tujuan untuk mengupayakan penanggulangan kanker anak, dengan menyelenggarakan kegiatan di bidang promotif, preventif, dan suportif. Yayasan ini menyediakan rumah singgah bagi orangtua yang akan membawa anaknya kemoterapi di beberapa rumah sakit rujukan di Kota Bandung, yaitu RSUP Dr. Hasan Sadikin dan RSU Al Islam. Setiap hari, hampir 30 orang tua dengan anak kanker tinggal di rumah singgah yayasan YKAKI.

Hasil wawancara yang dilakukan dengan Sekretraris YKAKI Bandung, mengungkapkan bahwa hampir seluruh orangtua anak kanker merasa khawatir dan takut dengan kondisi terburuk yang akan anak alami. Stres yang sangat luar biasa dirasakan semua orangtua pada saat mendapati kabar bahwa anaknya mengalami penyakit yang membutuhkan pengobatan sepanjang waktu. Wawancara dengan lima (5) orangtua menunjukkan, semua orangtua mengungkapkan bahwa penyakit pada anaknya mengganggu keseimbangan keluarga, baik dari segi fisik, psikologis, sosial, spiritual, dan ekonomi.

Orangtua harus dapat melakukan berbagai penyesuaian serta membantu anak untuk beradaptasi dengan penyakitnya. Orangtua harus mampu beradaptasi dalam menjalani kehidupan sehari-hari, termasuk dalam mengakomodasi kebutuhan anak sakit kronis, baik secara fisik maupun psikologis. Semua orangtua berupaya untuk menciptakan kehidupan normal dalam keluarga, sementara memiliki anak dengan penyakit kronis. Orangtua pun mengungkapkan bahwa mereka sangat 
memerlukan social support (dukungan dari berbagai pihak) selama proses adaptasi memiliki anak dengan kanker (cancer trajectory). Social support yang diperlukan dapat berasal dari petugas kesehatan, kader kesehatan dan relawan (volunteer), keluarga dan sesama orangtua yang memiliki anak dengan sakit kanker. Hasil wawancara yang dilakukan pada orangtua dan pengurus YKAKI Cabang Bandung menunjukkan bahwa kebutuhan dukungan yang utama yang diperlukan oleh orangtua adalah dari keluarga, tetangga (kader kesehatan dan relawan di daerahnya masing-masing), dan sesama orangtua yang memiliki anak kanker (peer). Oleh karena itu, diperlukan suatu upaya pemberdayaan untuk meningkatkan kader kesehatam, sesama orangtua yang memiliki anak dengan kanker (peer) melalui social support group dalam adaptasi dan normalisasi pada orangtua dengan anak kanker di rumah singgah YKAKI. Jadi kelompok sasaran dalam kegiatan ini adalah sesama orangtua, kader kesehatan dan relawan (community volunteer) yayasan YKAKI. Bidang kegiatan program/tema kegiatan program PPM ini yaitu berkaitan dengan bidang kesehatan dalam hal pemberdayaan social support group dalam adaptasi dan normalisasi pada orangtua dengan anak kanker di Kota Bandung.

\section{METODE}

Kegiatan ini berupa pemberdayaan kader kesehatan dalam mendukung adaptasi dan normalisasi keluarga dengan kanker di Yayasan YKAKI Bandung. Intervensi pemberdayaan kader kesehatan dalam kegiatan ini dilakukan melalui pendidikan kesehatan (penyuluhan) yang dilakukan setiap minggu selama 3 minggu. Penyuluhan menggunakan metode: ceramah dan diskusi (90 menit), simulasi (30 menit). Populasi dalam penelitian ini adalah sesama orangtua, kader kesehatan, dan volunter Yayasan YKAKI Bandung, teknik pengambilan sampel dengan cluster sampling, didapatkan 38 responden. Tujuan kegiatan ini untuk mengidentifikasi bagaimana peningkatan kemampuan kognitif dan psikomotor. Kemampuan psikomotor yang diharapkan dalam kegiatan ini adalam peningkatan skills orangtua dalam melakukan simulasi komunikasi efektif dalam memberikan dukungan pada keluarga lainnya. Intervensi pemberdayaan kader kesehatan dalam kegiatan ini dilakukan melalui pemberian ceramah, simulasi, small group discussion dan praktikum. Pengukuran pengetahuan diperoleh menggunakan kuesioner adaptive task for parent and caregiver yang dimodifikasi dari Canam, et.al (2012), sedangkan pengukuran kemampuan psikomotor berdasarkan cheklist observasi. Data dianalisis menggunakan analisis univariat, dan bivariat menggunakan dependent t-test.

\section{HASIL DAN PEMBAHASAN}

Berdasarkan hasil pre dan post test dari kegiatan pemberdayaan ini, seperti yang terlihat pada Tabel
1, didapatkan bahwa telah terjadi peningkatan pengetahuan dari peserta pelatihan. Dimana nilai rata-rata pre test adalah $65,20 \pm 0,20$ dan nilai post test $87,4 \pm 0,21$, dengan rata-rata peningkatan skor $22 \pm 0,1$. Hasil uji statistik menunjukkan terdapat peningkatan pengetahuan kader bermakna setelah dilakukan intervensi melalui pelatihan kader kesehatan $(\mathrm{p}=0,03 ; \alpha=0,005)$.

Tabel 1. Pengukuran Pengetahuan Responden tentang Adaptasi dan Normalisasi Pada Orangtua dengan Anak Kanker Sebelum dan Sesudah Intervensi Pemberdayaan Kader Kesehatan di Kota Bandung Bandung ( $=38)$

\begin{tabular}{llll}
\hline \multicolumn{1}{c}{ Pengetahuan } & Rerata & Standar Deviasi & Nilai p \\
\hline Sebelum & 65,20 & 0,20 & $0,03^{*}$ \\
Sesudah & 87,4 & 0,21 & \\
\hline
\end{tabular}

*Bermakna pada $\alpha=0,05$

Selanjutnya pada Tabel 2 dijelaskan kemampuan psikomotor responden dalam melakukan komunikasi efektif dukungan emosional dan psikososial pada orang tua yang memiliki anak kanker. Kegiatan ini diukur dengan menggunakan daftar ceklist observasi komunikasi efektif. Pengukuran dilakukan satu kali (one shot) yaitu setelah responden mendapatkan intervensi pemberdayaan kesehatan ini.

Tabel 2. Distribusi Frekuensi Pengukuran Kemampuan Psikomotor responden dalam Melakukan Komunikasi Efektif dukungan Emosional dan Psikososial Pada Orangtua dengan Anak Kanker setelah Mendapatkan Intervensi Pemberdayaan Kader Kesehatan di Kota Bandung Bandung $(\mathrm{N}=38)$

\begin{tabular}{lll}
\hline \multicolumn{1}{r}{ Kategori } & \multicolumn{1}{c}{ Frekuensi (f) } & Prosentase (\%) \\
\hline Baik & 41 & 100 \\
Kurang Baik & 0 & 0 \\
\hline
\end{tabular}

Berdasarkan tabel diatas, dapat dijelaskan bahwa pada kemampuan psikomotor dalam melakukan komunikasi efektif kader kesehatan pada orangtua menunjukkan bahwa, $100 \%$ responden memiliki kemampuan psikomotor yang baik, artinya responden tersebut mampu melakukan komunikasi dengan baik pada orangtua dengan anak kanker.

Hasil evaluasi pada kegiatan PPM ini menunjukkan bahwa pada saat dilakukan pelatihan terkait konsep kanker anak dan deteksi kanker anak, permasalahan yang dihadapi keluarga anak dengan kanker, dan pembentukan social-peer support group sebagai salah satu sumber dukungan bagi orangtua pasien kanker anak dalam adaptasi dan normalisasi di Yayasan YKAKI Bandung Kota Bandung Bandung, semua responden baik orangtua, kader kesehatan maupun volunteer yayasan sangat aktif dan antusias. Kegiatan ini dihadiri oleh 38 orang peserta yang terdiri dari 20 orangtua, 10 kader kesehatan dan 8 
orang pengurus yayasan. Kegiatan tersebut dilaksanakan di Aula Kantor Yayasan YKAKI Bandung.

Hasil skrining awal sebelum kegiatan PPM dimulai terkait pengetahuan peserta penyuluhan tentang konsep kanker anak dan deteksi kanker anak, permasalahan yang dihadapi keluarga anak dengan kanker, dan pembentukan social-peer support group sebagai salah satu sumber dukungan bagi orangtua pasien kanker anak dalam adaptasi dan normalisasi menunjukkan bahwa hampir setengahnya dari kader kesehatan (nilai rata-rata pretest 65) kurang mengetahui dan memahami konsep kanker anak dan deteksi kanker anak, permasalahan yang dihadapi keluarga anak dengan kanker, dan pembentukan socialpeer support group sebagai salah satu sumber dukungan bagi orangtua pasien kanker anak dalam adaptasi dan normalisasi dengan tepat dan benar. Pada saat pemberian materi, peserta sangat antusias, dan pada saat diskusi pun peserta sangat aktif dan antusias. Hal ini terbukti dengan banyaknya pertanyaan yang diajukan oleh peserta pada sesi diskusi. Hasil evaluasi menunjukkan bahwa terdapat peningkatan pengetahuan tentang konsep kanker anak dan deteksi kanker anak, permasalahan yang dihadapi keluarga anak dengan kanker, dan pembentukan socialpeer support group sebagai salah satu sumber dukungan bagi orangtua pasien kanker anak dalam adaptasi dan normalisasi dari nilai rata-rata pretest 65 menjadi nilai rata-rata posttest 87 dengan rata-rata peningkatan skor $22,2 \pm 0,12$.

Peningkatan aspek kognitif ini sangat penting dan menjadi salah satu tujuan dalam kegiatan ini mengingat dari berbagai penelitian yang telah dilakukan didapatkan bahwa aspek pengetahuan merupakan hal yang memengaruhi perilaku seseorang. Pengetahuan merupakan hasil dari tahu, dan ini terjadi setelah orang melakukan pengindraan terhadap suatu objek tertentu. Pengindraan terjadi melalui pancaindra manusia, yakni indra penglihatan, pendengaran, penciuman, rasa, dan raba. Sebagian besar pengetahuan manusia diperoleh melalui mata dan telinga. Pengetahuan atau kognitif merupakan domain yang sangat penting dalam membentuk tindakan seseorang (overt behavior) (Notoatmodjo, 2012).

Sebagaimana yang dinyatakan oleh Notoatmodjo, meningkatnya pengetahuan akan menimbulkan perubahan persepsi, kebiasaan dan membentuk kepercayaan seseorang. Selain itu, pengetahuan juga merubah sikap seseorang terhadap hal tertentu. Dari pengalaman dan penelitian terbukti bahwa perilaku seseorang yang didasari oleh pengetahuan, kesadaran dan sikap positif, maka perilaku tersebut akan bersifat langgeng (long lasting). Sebaliknya apabila perilaku itu tidak didasari oleh pengetahuan dan kesadaran, maka tidak akan berlangsung lama (Notoatmodjo, 2012).

Menurut Notoatmodjo (2012) pengetahuan seseorang dapat dipengaruhi oleh beberapa faktor, yaitu pengalaman, tingkat pendidikan, keyakinan dan fasilitas. Pengalaman dapat diperoleh dari pengalaman sendiri maupun pengalaman orang lain. Pengalaman yang sudah diperoleh dapat memperkuat pengetahuan seseorang. Pendidikan dapat membawa wawasan/ pengetahuan seseorang. Secara umum seseorang yang berpendidikan lebih tinggi akan mempunyai pengetahuan yang lebih baik dibandingkan dengan seseorang yang tingkat pendidikannya lebih rendah, sedangkan keyakinan diperoleh secara turun temurun dan tanpa adanya pembuktian terlebih dahulu. Keyakinan ini bisa memengaruhi pengetahuan seseorang baik keyakinan itu bersifat positif maupun negatif. Faktor lain yang memengaruhi pengetahuan seseorang adalah fasilitas sebagai sumber informasi yang dapat memengaruhi pengetahuan seseorang, seperti diadakannya pelatihanpelatihan, media radio, televisi, koran, majalah, dan buku.

Peningkatan aspek kognitif, dalam hal ini pengetahuan kader kesehatan tentang kanker anak dan upaya adaptasi-normalisasi keluarga dengan kanker, merupakan salah satu tujuan pelaksanaan PPM ini. Karena berdasarkan paparan diatas, dapat disimpulkan bahwa dengan pengetahuan yang baik mengenai penyakit kanker anak, tanda dan gejala serta komplikasinya, masalah yang dihadapi keluarga dengan kanker, strategi koping dan dukungan sosial yang dibutuhkan keluarga dan peran kader dalam membantu keluarga diharapkan kader kesehatan dapat berperan dalam mendukung kaluarga dengan kanker.

Selain aspek kognitif, aspek psikomotor merupakan salah satu aspek yang sangat penting bagi kader kesehatan dalam melakukan peran nya sebagai salah satu sumber dukungan bagi keluarga dengan anak kanker. Aspek psikomotor merupakan aspek yang berkaitan dengan keterampilan (skill) atau kemampuan bertindak setelah seseorang menerima pengalaman belajar tertentu. Hasil belajar aspek psikomotor dikemukakan oleh Simpson (2008) yang menyatakan bahwa hasil belajar psikomotor ini tampak dalam bentuk keterampilan (skill) dan kemampuan bertindak individu. Hasil belajar psikomotor ini sebenarnya merupakan kelanjutan dari hasil belajar kognitif (memahami sesuatu) dan dan hasil belajar afektif (yang baru tampak dalam bentuk kecenderungankecenderungan berperilaku).

Target aspek psikomotor yang dicapai dalam kegiatan ini responden mampu melakukan komunikasi efektif dengan keluarga dalam melakukan sharing, ventilasi perasaan orangtua dan memberikan dukungan emosional dan psikososial bagi orangtua dengan kanker. Hasil kegiatan menunjukkan bahwa seluruh peserta memiliki kemampuan komunikasi efektif dalam kategori baik. Selain itu, seluruh peserta PPM juga memiliki motivasi untuk memberikan dukungan emosional dan psikososial kepada keluarga dengan kanker. Motivasi merupakan hal yang sangat penting dan menjadi salah satu luaran dalam kegiatan ini. Motivasi adalah sebuah alasan atau dorongan seseorang untuk bertindak. Alasan atau dorongan itu bisa datang dari luar maupun dari dalam diri. Sebenarnya pada dasarnya 
semua motivasi itu datang dari dalam diri, faktor luar hanyalah pemicu munculnya motivasi tersebut. Motivasi dari luar adalah motivasi yang pemicunya datang dari luar diri kita. Sementara motivasi dari dalam ialah motivasinya muncul dari inisiatif diri kita. Selanjutnya, Samsudin (2005) memberikan pengertian motivasi sebagai proses memengaruhi atau mendorong dari luar terhadap seseorang atau kelompok agar mereka mau melaksanakan sesuatu yang telah ditetapkan. Motivasi juga dapat diartikan sebagai dorongan (driving force) dimaksudkan sebagai desakan yang alami untuk memuaskan dan mempertahankan kehidupan. Chung dan Megginson mendefinisikan motivasi sebagai perilaku yang dirumuskan sebagai perilaku yang ditujukan pada sasaran.

Setelah kegiatan ini dilakukan, peserta memiliki komitmen untuk melakukan deteksi dini kanker pada anak di lingkungan setempat dan akan memberikan dukungan emosioal dan psikososial pada keluarga dengan kanker, dalam bentuk kunjungan rumah. Setelah kegiatan ini dilakukan,selanjutnya akan dilakukan rencana kegiatan lain yaitu pembentukan social support group di yayasan, dan implementasi kegiatan social support group berupa sharing, diskusi dan kegiatan keagaamaan bersama yang dilakukan oleh social support group.

Program pengabdian pada masyarakat ini perlu ditindaklanjuti dengan melakukan beberapa perencanaan lanjutan yaitu pembentukan social support group yayasan. Pembentukan social support group ini akan diinisiasi oleh pengurus yayasan dan orangtua yang sudah mengikuti pelatihan ini. Social support group ini terdiri dari kader kesehatan, tokoh masyarakat peduli kanker, dan keluarga dengan kanker yang akan terinegrasi. Adanya social support group ini berfungsi sebagai wadah untuk saling berbagi, saling support, pemantauan kesehatan keluarga dengan anak kanker, dan peningkatan upaya adaptasi dan normalisasi bagi keluarga dengan anak kanker.

\section{SIMPULAN}

Pelaksanaan pemberdayaan social support group dalam adaptasi dan normalisasi pada orangtua dengan anak kanker di Kota Bandung Bandung dapat dilaksanakan dengan baik, beberapa kegiatan yang sudah dilakukan, yaitu: rapat koordinasi tim pelaksana untuk persiapan kegiatan PPM, rapat koordinasi tim pelaksana kegiatan PPM Prioritas untuk identifikasi sasaran dan kebutuhan penyuluhan/pelatihan, pengajuan ijin kegiatan pelaksanaan PPM Kantor Yayasan YKAKI Kota Bandung, rapat koordinasi tim pelaksana PPM Prioritas dengan Tim Yayasan YKAKI Kota Bandung Bandung, rapat koordinasi tim PPM untuk persiapan pelaksanaan kegiatan PPM (membuat susunan acara untuk jadwal kegiatan PPM dan membuat materi kegiatan PPM), rapat koordinasi tim PPM untuk finalisasi persiapan pelaksanaan kegiatan PPM, dan kegiatan penyuluhan kesehatan, dan pemberdayaan social support group dalam adaptasi dan normalisasi pada orangtua dengan anak kanker, supervisi hasil pemberdayaan social support group, diseminasi hasil pelaksanaan kegiatan dan rencana tindak lanjut kegiatan PPM Prioritas pemberdayaan social support group, dan pembuatan laporan akhir kegiatan, catatan kegiatan harian, laporan keuangan, dan penyusunan artikel untuk publikasi ilmiah kegiatan PPM Prioritas.

Melalui kegiatan PPM Prioritas ini, pengetahuan dan kemampuan orangtua, kader kesehatan/relawan (community volunteer), dan pengelola Yayasan YKAKI Cabang Bandung meningkat dalam pemberdayaan social support group. Hal ini dapat terlihat dari hasil kegiatan ini menunjukkan adanya peningkatan pengetahuan yang bermakna dari rata-rata $65,20 \pm 0,20$ menjadi $87,4 \pm 0,21$, dengan rata-rata peningkatan skor $22,2 \pm 0,12$ $(p=0,0043 ; \alpha=0,005)$. Selain itu, pada kemampuan psikomotor dalam melakukan komunikasi efektif, hasil kegiatan juga menunjukkan bahwa $100 \%$ peserta memiliki kemampuan psikomotor yang baik, artinya peseta tersebut mampu melakukan komunikasi dengan baik pada orangtua dengan anak kanker, dimana komunikasi efektif ini merupakan hal yang sangat penting bagi kader kesehatan dalam memberikan dukungan pada keluarga, baik dukungan emosional maupun dukungan psikososial.

\section{UCAPAN TERIMAKASIH}

Kegiatan Pengabdian Masyarakat berupa Pemberdayaan Social Support Group dalam Adaptasi dan Normalisasi Pada Orangtua dengan Kanker Anak di Kota Bandung Bandung ini dapat terlaksana atas fasilitasi Hibah Pengabdian Pada Masyarakat (PPM) Prioritas yang dibiayai oleh Universitas Padjadjaran, melalui sesuai Surat Tugas Pelaksanaan Kegiatan Pengabdian Kepada Masyarakat Nomor: 899/ UN6.L/PL/2018 tanggal 8 Maret 2018. Oleh karena itu, tim PPM menyampaikan ucapan terimakasih kepada semua pihak yang telah membantu pelaksanaan kegiatan ini yaitu: Rektor Universitas Padjadjaran; Direktur Riset, Pengabdian Pada Masyarakat dan Inovasi Universitas Padjadjaran beserta jajarannya; Dekan Fakultas Keperawatan, Ketua Pusdi Keperawatan Berkelanjutan, Ketua Yayasan Kasih Kanker Anak Indonesia Cabang Kota Bandung dan Seluruh kader ksehatan serta orang tua yang memiliki anak kanker di Kota Bandung Bandung.

\section{DAFTAR PUSTAKA}

Bender, B., Annett, R., Ikle, D., DuHamel, T., Rand, C., \& Strunk, R. (2000). Relationship between disease and psychological adaptation in children in the childhood asthma management program and their families. Archives of Pediatrics and Adolescent Medicine, 154(7), 705-713.

Coffey, J.S. (2006). Parenting a child with chronic illness: A metasynthesis. Pediatric Nursing, 32(1), 51-5.

Costello, E.J., Foley, D.L., \& Angold, A. (2006). Ten year research update review: The epidemiology of child 
and adolescent psychiatric disorders. Journal of the American Academy of Child and Adolescent Psychiatry, 45(1), 8-25.

Depkes RI. (2011). Press release hari kanker anak sedunia. Diperoleh dari http://www.dinkesjabar. go.id tanggal 20 Agustus 2017.

Gatot, D. (2008). Deteksi dini kanker anak. Diperoleh dari http:/www.dinkesjabar.go.id tanggal 20 Agustus 2017.

Herminia, P., \& Joao, B. (2006). Issues associated with chronic disease. In: Health and Safety. Tersedia pada: http://www.eselx.ipl.pt/healthandsafety/ chronic/psycho.htm.

Hockenberry, M.J., \& Wilson, D. (2012). Wongs's essentials of pediatric nursing ( $8^{\text {th }} \mathrm{Ed}$.). St. Louis Missouri: Mosby Elsevier.

Huang, M-C. (2003). Normalization: Styles of family management of children with chronic illness. $H u$ Li Za Zhi The Journal of Nursing, 61-65.

Kementerian Kesehatan RI. (2013). Kanker Anak di Indonesia. Jakarta: Kementerian Keehatan RI.

Knafl, K.A., Darney, B.G., Gallo, A.M., \& Angst, D.B. (2010). Parental perceptions of the outcome and meaning of normalization. Res Nurs Health, 33(2), 87-98. doi:10.1002/nur.20367.

Knafl, K.A., \& Deatrick, D.A. (2002). The challenge of normalization for families of children with chronic conditions. Pediatric Nursing, 28(1), 49-56.

Knafl, K.A., Deatrick, J.A., Knafl, G.J., Gallo, A.M., Grey, M., \& Dixon, J. (2013). Patterns of family management of childhood chronic conditions and their relationship to child and family functioning. J Pediatr Nurs, 28(6), 523-535. doi:10.1016/j. pedn.2013.03.006.

McClellan, C.B., \& Cohen, L.L. (2007). Family functioning in children with chronic illness compared with healthy controls: A critical review. The Journal of Pediatrics, 150(3), 221-223. DOI: 10.1016/j.jpeds.2006.11.063.

McCloskey, J.C., \& Bulechek, G.M. (2000). Nursing intervention classification (NIC): IOWA intervention project. St. Louis: Mosby.

McMullen, A., Yoos, H.L., Anson, E., Kitzmann, H., Halterman, J., \& Arcoleo, K. (2007). Asthma care of children in clinical practice: Do parents report receiving appropriate education?. Pediatric Nursing, 33(1), 37-44.

McQuaid, E., Walders, N., Kopel, S., Fritz, G., \& Klinnert, M. (2005). Pediatric asthma management in the family context: The family asthma management system scale. Journal of Pediatric Psychology, 30(6), 492-502.

Meijer, S., Sinnema, G., Bijstra, J., \& Mellenbergh, G. (2012). Social functioning in children with chronic illness, The Journal of Child Psychology and Psychiatry and Allied Disciplines, 41, 309-317.

O'Neal, C.A.S. (2007). The development of the normalization assessment measure. Dissertation. Faculty of the Graduate School of Vanderbilt University.

Peck. B., \& Lillibridge, J. (2005). Normalization behaviours of rural fathers living with chronicallyill children: An Australian experience. Journal of Child Health Care, 9(1) 31-45. DOI: 10.1177/1367493505049645.

Puspita, S.Z., \& Ludiro, S.K. (2013). Kondisi orang tua pasien kanker anak dilihat dari aspek biopsikososial berdasarkan fase pengobatan anak (studi deskiptif pada support group sebagai program dalam komunitas pita emas Rumah Sakit Kanker Dharmais Jakarta). Fakultas Ilmu Sosial dan Ilmu Politik, Jurusan Ilmu Kesejahteraan Sosial, Universitas Indonesia, Depok, Indonesia.

Sarafino, E.P. (2008). Health psychology: Biopsychosocial interactions $\left(6^{\text {th }}\right.$ Ed.). New York: John Wiley \& Sons.

Shah, N., Harrington, T., Huber, M., Wellnitz, C., Fridrych, S., Lasers, G., et al. (2006) Increased reported cases of tuberculosis among children younger than 5 years of age. The Paediatric Infectious Disease Journal, 25, 151-155.

Theofanidis, D. (2006). Chronic illness in childhood: Psychosocial adaptation and nursing support for the child and family. Health Science Journal, 2.

Wenar, C., \& Kerig, P. (2008). Developmental psychopatology from infancy through adolescence. New York: McGraw-Hill.

Wirlach-Bartosik, S., Schubert, M., Freilinger, M., \& Schober, E. (2005) Family dynamics and chronicillness: Children with diabetes in the context of their families. Clinical Paediatrics, 217, 253-258.

Wong, D.L. (2013). Nursing care of infant and children $\left(10^{\text {th }} \mathrm{Ed}\right.$.). St. Louis: Mosby Year Book, Inc.

Yayasan Kanker Indonesia (YKAKI) Cabang Bandung (2017). Profil dan permasalahan kanker di Bandung. Diperoleh melalui: www. YKAKIBandung.org 